\title{
JUÍZO PARALISADO
}

\author{
KATHRIN ROSENFIELD explica por que, quase contra a vontade, \\ se reconciliou com o pensamento de Heidegger
}

Lembro num passado mais recente um interessante erro de avaliação que me aconteceu com o romance de J. M. Coetzee, Diário de um ano ruim. Li algumas páginas e fiquei irritada, pois pensei já ter adivinhado para onde ia levar esta história do homem envelhecido que se encanta com a moça gostosa que frequenta a lavanderia do prédio exibindo suas curvas. Lembrava os inícios dos contos desalmados de Carver de que eu tinha gostado até um dia simplesmente cansar do gênero. Com esse tédio em mente, quase larguei o livro, não tivesse um amigo retificado meu juízo, o que levou à descoberta de um romance maravilhoso que li e reli várias vezes.

Mas esse é um caso menor e menos grave que os erros mais "ancorados" em sistemas de convicção coletivos que simplesmente paralisam nosso juízo, nossa capacidade de ver e avaliar de modo autônomo. Esse erro também cometi, por exemplo, com Jung e Heidegger. Como tantos de minha geração, Heidegger era o pensador suspeito número um e nem sequer a amizade e admiração duradouras de Hannah Arendt foram capazes de me inspirar uma abertura mais crítica. Quem olha pelo ângulo da suspeita encontra, é claro, tudo aquilo que confirma o comprometimento do pensador com o nazismo: os temas (gleba, solo, terra, luta), a escolha das obras como o templo grego, dos autores e topoi patrióticos, dos rios germânicos, o patos solene e... a omissão dos autores contemporâneos relevantes - Musil e Mann, Döblin e Brecht, entre muitos outros.

E devo dizer que nem hoje superei completamente os preconceitos com relação à ontologia heideggeriana: pois, mesmo quando queremos superar nossas limitações, uma aversão cultivada durante muito tempo nos prega peças. Apenas cheguei a reconhecer, tardiamente e quase 
contra vontade, o quanto o pensamento de Heidegger recorta - e provavelmente influenciou desde o início - minhas próprias críticas à Estética hegeliana ou a minha leitura de Hölderlin. Me defendi contra a influência heideggeriana fixando os olhos na crítica de Adorno, que diz no seu ensaio Parataxis:

\footnotetext{
Não há como contrastar e opor nada ao método heideggeriano. Ele erra na medida em que, enquanto método, afasta-se da matéria poética (Sache); [e ao] infiltrar naquilo que é filosoficamente carente na poesia de Hölderlin uma filosofia importada do exterior. Trata-se de encontrar o corretivo onde Heidegger interrompe [sua interpretação] a favor do tema a ser provado: na relação do conteúdo (também do conteúdo de pensamento) para com a forma.[1]
}

Mas, ao pensar praticar um método totalmente diverso, a influência de Heidegger, na verdade, veio à tona. Não posso negar o que meus colegas (heideggerianos ingleses e americanos) percebem de imediato: que minhas interpretações de Antígona e de Édipo Rei ampliam, como hermenêutica das obras integrais, as sugestões heideggerianas de abordagem da obra de arte: leituras dos detalhes insignificantes, escuta do nada e do silêncio com o qual dialogam as formas manifestas, cuidado pelas tensões implícitas que estruturam o texto (ou a imagem) à revelia das significações manifestas.

Pois mesmo quem se despojou do vocabulário típico de Heidegger e dos seus seguidores - ente, ser, différance etc. - pode navegar nas correntes trilhadas por ele. E provavelmente teria sido menos custoso defender-se (em vão) destes caminhos trilhados.

[1] ADORNO, Theodor W. in Noten zur Literatur III, 182

KATHRIN ROSENFIELD é doutora em Ciência da Literatura pela Universidade de Salzburg (Áustria) e professora do Depto. de Filosofia da UFRGS. É autora de Grande Sertão: veredas roteiro de leitura (Topbooks, 2008), Antigone: Sophocles 'Art, Hölderlin's Insight. (The Davies Group, Publishers, 2010) 